\title{
Private vs. Public
}

\section{Entrepreneurial Library Services for Children in China}

JON JABLONSKI

A t 8:30 on a cold November Sunday morning in 2014, I met Echo Liu in southern Beijing, an hour's drive away, far from the renovated alleyways and Forbidden City of the city center.

Echo and a handful of helpers were busy preparing her children's library, a library that she owns and operates as a private business, for a 9 a.m. storytime and craft activity that would feature a foreign visitor.

The Baby Cube Children's Library is in a two-story round building. The library fills the first floor's approximately three thousand square feet, and it is filled with white curved bookshelves packed with board books, picture books, storybooks, and chapter books. Child-sized furniture surrounds a central adult-sized round booth with an egg-shaped, subtly-lit dome over it. There is a low stage, with a twenty-foot screen and digital projector. There is a circulation desk with a barcode scanner.

Baby Cube is a private membership library, with annual dues of about $\$ 200$ operating in a city of 20 million people that has exactly eight public libraries. ${ }^{1}$ Similarly populated, the greater Los Angeles metro area has more than two hundred public libraries. $^{2}$

Echo opened the Baby Cube in 2009 in a smaller space. Today, she subsidizes it with another business-a successful children's publishing house located conveniently on the second floor of her jaunty building. As part of her market research and as a service to the community, she has compiled a directory of more than 1,700 of these private children's libraries in cities large and small all over China. ${ }^{3}$

When we spoke in 2015, she was on track to publish more than 170 titles by year's end. In 2017, she planned to open an office in Vancouver, Canada.

The phenomenon of private membership libraries is not unique. In fact, public libraries as we know them can be considered to be descended from rental libraries that traded in popular reading in Victorian England. ${ }^{4}$ However, private subscription libraries for children are virtually unknown in North America. The only comparable institution is the Books and Me Library, a Silicon Valley-based picture book library

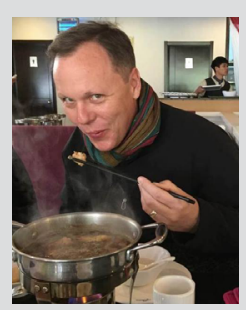

Jon Jablonski is geospatial data librarian and director of the Interdisciplinary Research Collaboratory at the University of California Santa Barbara Library. He holds an MLIS from the University of Washington and an MA in Geography from the University of Oregon. In addition to continuing his study of how children's libraries are evolving in China, he works on the long-term preservation of born-digital geographic information and volunteers as an adult literacy tutor at the Santa Barbara Public Library. 
that caters to the language needs of area children born to Chinese parents.

This article describes common traits and unique aspects of private children's libraries in China based on five visits to China, taking in more than thirty-five libraries in eight cities between 2011 and 2017. These visits included discussions with owners and staff, storytimes, and question-and-answer sessions with parents and grandparents.

\section{Background}

Baby Cube is one of China's oldest private children's libraries. Many of the earliest have already closed their doors. Small businesses come and go quickly in China, and these libraries are no different. I first learned of the libraries in 2011 while teaching library school in the Yangze River city of Wuhan.

Tricia Wang, a sociologist from UC San Diego at the time, introduced me to Meng Fanyong, who led us by city bus to two libraries on a sweltering spring afternoon. Before leaving Wuhan, I visited Meng at his soon-to-open mother's book bar and lending library. All three of these libraries asked for advice on how to maximize revenues, choose relevant books, inspire parents to read to their children, and motivate those same children to be independent readers. In 2014, these were many of the same questions that I received while interviewing library owners and parents.

All three of those Wuhan libraries are now closed, replaced by at least six others I know to be operating now in Wuhan. Today, Meng has relocated to Beijing, married, had a daughter, and moved his parents to the city. After working at a stateowned children's publishing house and a Big Data analytics startup, he recently started his own company. In the seven years since we first met, he has remained a close collaborator: arranging visits, sharing his contacts, and patiently sharing his life story through our language barrier. With four other advocates, we have founded ReadingEverywhere.org to provide a framework for working with this community of children's library entrepreneurs.

The phenomenon of these libraries operating as businesses is about twelve years old in China, but little has been written about them. A trade magazine identifies the House of Aesop's Fables as the first membership children's library in China, opened by a Taiwanese investor in $2006 .{ }^{5}$

They appear as a minor category of private libraries in a 2013 article that describes charity libraries and book corners donated to rural schools as the dominant model of private libraries in China. ${ }^{6}$ Privately run children's libraries in China have also been briefly mentioned in Publisher's Weekly in the context of the children's book industry, ${ }^{7}$ and they have been mentioned in relation to the political troubles of a non-profit providing library services to rural children. ${ }^{8}$

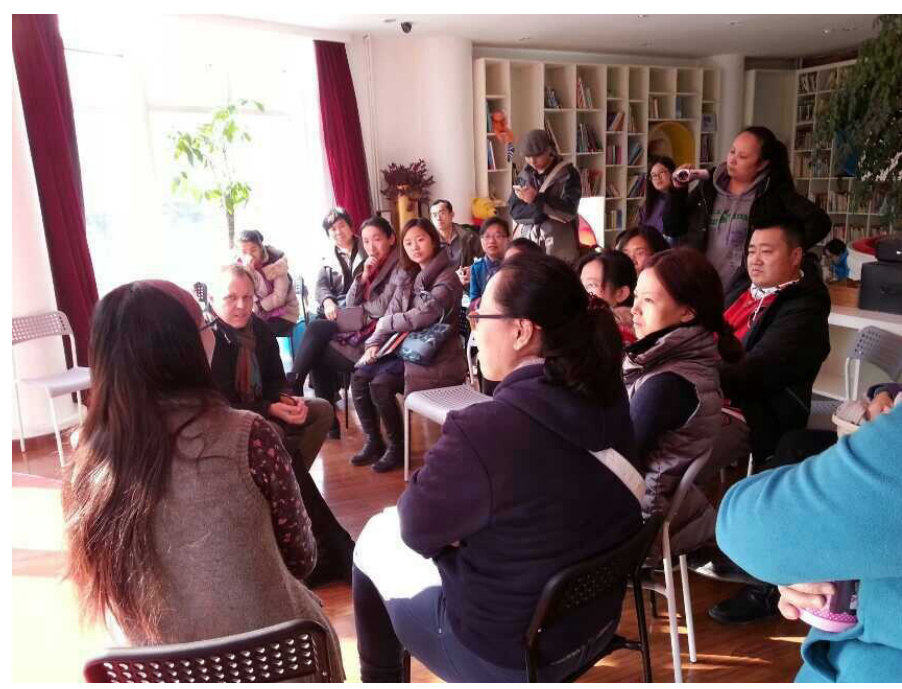

Participants in an early-morning storytime and parental Q\&A listen to Echo Liu, owner of Beijing's Baby Cube Library and children's publishing house, respond to one of the author's points.

Some suggest that the concept has been imported from Japan. The first "bunko," as they are known there, may have been opened in the house of a children's book author in 1906, and bunkos may have numbered about four thousand in the mid2000s, ${ }^{9}$ yet they appear only briefly in the English language library literature, first in an IFLA presentation, ${ }^{10}$ later in a brief survey, ${ }^{11}$ and finally in a longer study regarding their operation. ${ }^{12}$

The standard model for the libraries is that a family pays between 600 and 1800 RMB (between $\$ 100$ and $\$ 300$ US) per year for book borrowing privileges. Every other service you would expect from an American public library is on offerbook clubs for young parents, mid-morning storytimes for preschool children, after school homework help, and weekend craft activities.

Just as in the United States, many libraries do not limit themselves to book-centric activities. Libraries also offer local and overnight field trips, birthday parties, and cooking classes. At a library above a northern Beijing mall, not far from the Bird's Nest Olympic Stadium, my visit was cut short by a singing class taking over the room. Quite a few library operators subsidize their operations with these sorts of activities, or they share space with a loose-knit collection of child-centric businesses: art teachers, music teachers, English schools, and librarians cooperatively operating spaces.

\section{Recent Historical Context}

The generation of parents currently in their late twenties and early thirties were born shortly after China imposed its one child policy. One year earlier, China had opened its markets to the outside world, starting a period of rapid economic growth. Their parents, the grandparents who I met accompanying their preschool-aged grandchildren to workday storytimes, suffered very real deprivations, and often physical 
violence, during the Cultural Revolution. If these grandparents were originally urbanites, there is a good chance that they were sent to the countryside for reeducation at some point in their teens and twenties.

The effects of the Cultural Revolution are subtle for today's generation of parents. Most young Chinese parents have only ever known China as the rapidly developing and urbanizing economic powerhouse that Americans see in the news. However, recreational reading in China often carries with it lingering stigma created by Cultural Revolution. People over the age of fifty lived through a period when most literature other than a Little Red Book was strictly forbidden. If you've read the book or seen the movie Balzac and the Little Chinese Seamstress, the prohibition on books and literature is not exaggerated.

This rapid cultural change plays out differently for every family. Some grandparents are scolded for disciplining children too harshly (and of course, some for spoiling them). Sometimes it is the grandmother scolding her professional daughter for allowing too much screen time or putting too much pressure on young children in the form of weekend English lessons or extra math tutoring designed to improve standardized test scores, which are crucial for college admission for the vast majority of the population that cannot afford to send their children overseas.

During one question-and-answer period in the northern Beijing suburb of Changping, one grandmother sat up and applauded when I suggested that reading time in the household should apply equally to everyone. The notion that children grow into independent readers by emulating the adults in their lives struck a tone in the room, and I made sure to incorporate the answer into subsequent presentations. Sometimes the older generation offers a surprisingly progressive view. The father of a Western Beijing library owner beamed with pride when I asked him about his daughter's business, saying how great it was that she manages a business that provides such an enriching environment for the children of the local neighborhood.

\section{Library Operations and Environments}

About thirty children, parents, and grandparents showed up that morning at Baby Cube to hear a story about why there's no cat in the Chinese zodiac (the rat tricked him) and to make soap in the shapes of zodiac animals (which was the craft activity that kept the kids occupied while the strange foreign visitor talked with their parents).

Weekends are the busiest days at the libraries, with Sundays the busiest days. Saturdays are workdays for many Chinese parents, and many children over the age of seven spend the day at English, piano, calligraphy, computer, and of course test preparation classes, so traffic in the libraries is a bit lower.

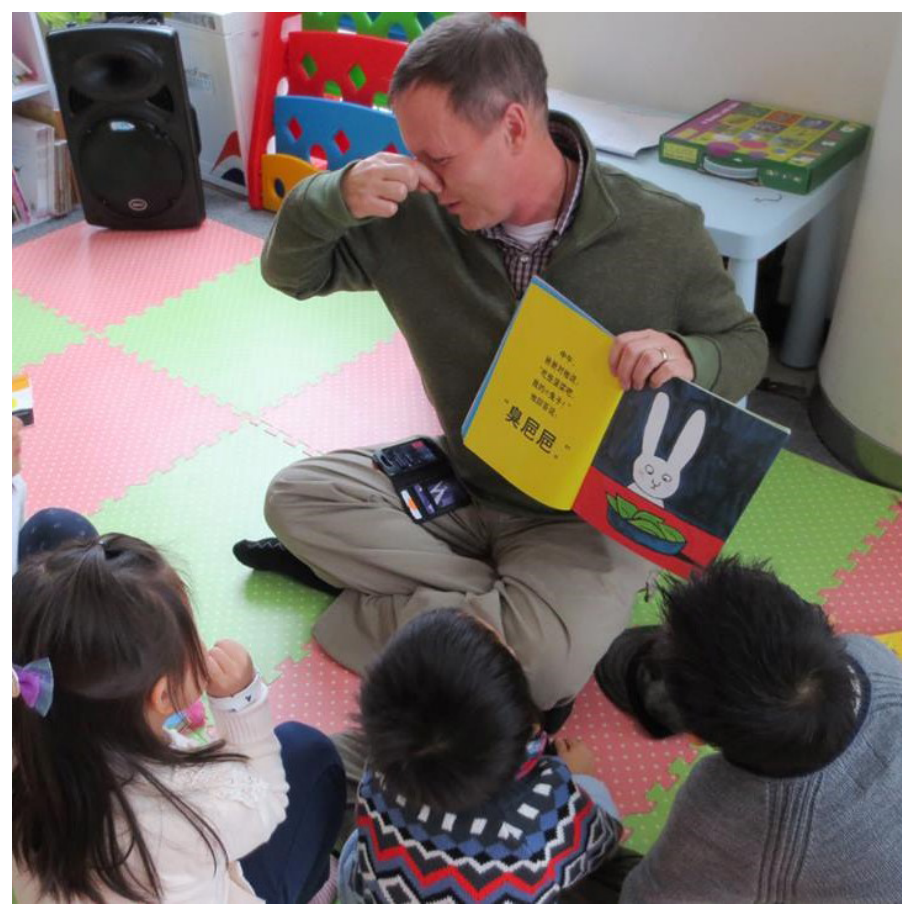

The author reads Stinky Poop to members of Li Na's Little Leaves children's library in Shanghai.

Even knowing this, I was surprised by the large audience and the logistics of the setup. The storyteller used a headset microphone, a scanned version of the book was projected on the screen, and the storytime started with a call-andresponse that told me the kids were familiar with the format. This was the ninth library of my 2014 visit, and while each had been different, this was the first that had arranged such a detailed program.

Weekdays have a pattern not unlike the children's room of an American public library-preschool children in the mornings, more on days with a storytime. After the post-lunch nap, kindergartners arrive with aunties or grandpa in tow. In most two-parent Chinese households, especially those of the college educated, who are the primary users of these libraries, both parents work and a retired relative provides the bulk of child care. As the afternoon wears on, there is a slow trickle of primary school students-but few older than ten. After-school activities, mostly academic, dominate for the young-adult demographic and result in what everyone agrees is an underdeveloped YA book market.

The librarians themselves tend to be parents. Some left careers connected to early childhood development to open their libraries. Others left private-sector jobs in information technology, human resources, and insurance. Eighty percent of the librarians I met are women, and quite a few of these are mothers who decided to open their own businesses rather than return to their jobs after their legally-mandated ninetyeight day (longer in some jurisdictions) paid maternity leaves.

Almost every single person who shared their financial status with me reported that their library operates off of family 
surplus income. Naturally, some families have more surplus than others, and at times I sensed some tension when I asked about how the library has affected family life for the librarian. Like Baby Cube, other libraries operate alongside businesses that subsidize library operations. For example, Nanchang's Century Library is the first floor retail tenant of its parent company-a children's publishing house that owns the thirty-story high-rise building in which both reside.

The Century Library also distinguishes itself with its extensive operating hours-seven days a week until 8:30 p.m. Moreover, this was the only library I visited with a cafe or teashop on the premises.

During our interview, I was offered cappuccino repeatedly until my translator Klaus gently whispered to me that they really wanted me to try the coffee. Coffee in China is generally dreadful, but this was excellent. Klaus, whose day job is translating for the German technicians repairing 100RMB banknote printing presses, rightly observed that the tea and coffee were exceptionally inexpensive-about one-third the cost of Starbucks - and were probably a loss leader encouraging parents to linger as their kids browsed the bookshelves.

Many of the libraries are on the upper floors of apartment buildings, many of which have retail tenants on the first few floors or immediately outside the gates of the walled compounds so prevalent in urban China. Most of the remaining libraries that I visited inhabited those lower-floor retail spaces. Three were in townhouses. One standout is Wuhan's Eastern Mom's Picture Book Gallery, which in 2014 was operating on the top floor of a brand new fourstory bookstore on new shopping and entertainment street, reminiscent of a mid-1990s flagship Border's or Barnes and Noble.

However, large bookstores are in trouble in China as well as in the United States. Revisiting in early 2017, the bookstore now has much more space devoted to gifts and
Are the Chinese waiting for their own Andrew Carnegie? Someone who can make a paradigm-changing donation and spur governments to invest in community library services? hundred volunteers and a single paid employee (although that position was vacant when I visited).

Firefly, divided equally between Chinese- and Englishlanguage books, was started with the private funds of two women-one foreign, one Chinese-who were no longer involved with the day-to-day operation. My informant, a new mother who is considering her post-maternity leave options, reported that the library is financially stable but is challenged logistically by its volunteer model.

The Smiling Library, founded by a group of mountaineering friends, has been donating money, books, and teacher training in rural areas for more than a decade and recently moved into urban areas. Two full-time employees in Chengdu, the capital of Sichuan Province, have trained the residents of twenty-two housing compounds to run libraries for local children.

All of the libraries are challenged. Qualified employees are hard to find. Library employees, frequently referred to as teachers, tend to be recent college graduates from a variety of fields outside of librarianship. I have yet to find any sort of children's librarianship training in Chinese library schools, and my students at Wuhan University reported that courses were unheard of.

Librarians report struggling to keep children interested in the services for more than a few months. Some libraries are located in shoddily constructed buildings that are not aging well. Poorly insulated windows and concrete walls lead to condensation, staining, and mold. Several of the owners visibly blanched when discussing revenues. More than one woman hinted that her husband was tired of her expensive "hobby."

In 2011, all three of the original librarians I met asked me to return with business advice. In 2014, one of my standard questions was to ask handicrafts, and the library has downsized into a different space that now markets itself as a village story center, concentrating on parenting skills.

I found two not-for-profit libraries and a network of volunteerrun libraries sponsored by a private foundation in Shanghai. The Edelweiss Library is well inside the walls of its suburban Beijing housing compound, on a floor designed to be a communal space. The founder of the library is a minor district official and demanded a children's library and a senior center be included in the master plan for the community.

The Firefly Library in Shanghai is in a vintage French Concession townhouse. Firefly is run by a cadre of two what sorts of assistance might help the libraries. Most asked for advice on how to expand membership and increase profit. Reinterviewing four library owners in 2015, sustainable business models and increasing revenues were still on all of their minds. One librarian, after losing a business partner, was developing a plan to apply for financial assistance from the district government. By 2017, that library had merged with a private kindergarten-an industry that is exploding in China due to limited spaces in public kindergartens, which children attend for three years. Echo readily admits that Baby Cube the publishing house subsidizes Baby Cube the library-calling the library "a gift for my daughter." The other two librarians who I reinterviewed in 2015 struggle to make ends meet. 
In 2014 and 2015, the one library owner who shared no financial concerns admitted to being independently wealthy. When asked, he denied that his library was a community service. "I just find it interesting," he told me, insisting that it was a social experiment enabled by his considerable personal wealth. When I revisited that city in 2017, his library was closed.

The industry appears to be growing but remains unstable. These librarians believe that modern, developed societies need libraries, and if the government is not going to provide the service, entrepreneurs will. In 2014, a bookstore manager reported meeting a number of people at the Shanghai China International Children's Book Fair who were opening libraries. At that same fair a year later, by a show of hands, most of the one hundred or so attendees at a presentation worked at, or planned to open, a children's library.

At the Century Library, I spent about four hours with head librarian Sasha and an assistant on a Sunday evening, capped off with a crowd of fifty adults for a storytime and Q\&A session. Here in particular, people pressed me for information. "What do you think of this place?" (Answer: Better than the children's section of most of the American public libraries I have visited.)

"What are the best books for teaching our children English?" (Answer: You should be concentrating on reading as much as possible - read whatever you have access to and whatever holds your child's interest.)

"Are these books as good as the ones you have in America?" (Answer: Many of these books are the SAME as the ones we have in America.)

The new and growing Chinese middle class has a huge vested interest in making sure their kids get into college. Providing developmental advantages and personal enrichment to their children is the dominant topic of conversation in interview sessions, in Q\&A sessions, at lunch, and in all of my other interactions with parents and librarians. China is home to extremely high-stakes high school and college entrance examinations.

Admission to one of Beijing or Shanghai's elite public high schools virtually guarantees entrance to an elite universitywhether one is the child of a party official or a cab driver. All large cities have such tiered high school systems and are filled with commercial enterprises offering children after-school and weekend lessons in math, science, and English—all with the goal of beating the entrance examinations.

Some of the parents chafe against this system, and many of the librarians join them in arguing that the picture book libraries are there to offer an alternative to the entrance exam/childhood development industrial complex. One librarian pointed to the local kindergarten visible from her library's window and angrily denounced the rigid classroom discipline and rote memorization imposed on even the youngest students. For these parents and librarians, the libraries are a sanctuary for unstructured play, self-directed exploration, and one-onone parent-child bonding. In multiple venues, I found posters describing Jane Nelson's Positive Discipline parenting style. Two of the people I have met are organizing parenting workshops, and even a line of products, based on these tenets. Positive Discipline is popular with Chinese parents because, they tell me, it offers a "middle way" that aligns nicely with the ideas of a resurgent Confucianism.

\section{Future Prospects}

This is not a stable industry. All three of the Wuhan libraries I visited in 2011 were closed by 2014 . The most successful libraries are subsidized by other businesses or otherwise act as not-for-profits. Librarians report that they struggle to stay open. They have high member turnover as children turn ten and get involved preparing for the high school entrance exam. They have a hard time finding employees who can engage children and parents.

On the other hand, there continue to be new private libraries everywhere I look. Chains and franchises offer economies of scale and logistical expertise. An investment fund that specializes in educational ventures is investigating the industry. Echo reports being approached to open more Baby Cubes.

In 2017, a cellphone app similar to Yelp showed at least ten libraries in every city I searched. Some people believe that city governments will contract out neighborhood library services to those who already have experience in the space. Already, the Capitol Library, Beijing's public municipal library, offers training workshops for the city's private librarians.

It is very possible that the picture book libraries are an intermediate stage just like subscription libraries were in the West. Are the Chinese waiting for their own Andrew Carnegie? Someone who can make a paradigm-changing donation and spur governments to invest in community library services? District governments-most comparable to New York's borough governments-are already experimenting with library services, and in October 2017, I explored several branch libraries in the city of Suzhou that were similar to American neighborhood libraries.

Whether private libraries persist or not, the entrepreneurial children's librarians of China have created a vibrant ecosystem of library services. Even with their struggles, it has been easy to identify people who are successfully sustaining their libraries, paying living wages to their employees, regularly offering creative programming to their users, and constantly thinking about how to better help their parents and children.

I have to admit that before meeting these librarians, I assumed that general library services for children could only survive as 
a government-supported service. If the private libraries fade away in favor of government libraries, will that be a gain or a loss for librarianship? If they persist as the Communist Party continues China's transition to a market economy, what other assumptions about libraries will need to be questioned? What lessons can we learn from the Chinese about running our own libraries? ¿.

\section{References}

1. "Libraries and Book Bars in Beijing, China," accessed July 30, 2017, www.travelchinaguide.com/cityguides /beijing/library.htm.

2. Based on an analysis of a national dataset: "Public Libraries Survey," Institute of Museum and Library Services, accessed February 1, 2018, www.imls.gov/research -evaluation/data-collection/public-libraries-united -states-survey/public-libraries-united.

3. George P. Landow, "Mudie's Select Library and the Form of Victorian Fiction,” 1972, last modified July 25, 2016, www.victorianweb.org/economics/mudie.html.

4. Ibid.

5. Minjie Chen and Betsy Hearne, "New House on the Block: Private Children's Libraries in China," Horn Book Magazine, Oct. 9, 2012, 52-57.

6. Wang Zizhou, Yin Peili, and Wu Hanhua, "Private Libraries in China: Their Diversity, Informatization, and Role as Public Spaces," Library Trends 62, no. 1 (November 1, 2013): 160-79, doi:10.1353/lib.2013.0025.

7. Leonard S. Marcus, “Children's Books in China: A Q\&A with Xiaoyan Huang,” Publisher's Weekly, September 11,
2014, www.publishersweekly.com /pw/by-topic /childrens/childrens-industry-news/article/63970 -children-s-books-in-china-a-q-a-with-xiaoyan-huang .html; Karen Raugust, "Children's Publishing in China: Highlights from the First GKC China Deep Dive," Publisher's Weekly, Dec. 8, 2015, www.publishersweekly.com /pw/by-topic/childrens/childrens-industry-news/article /68894-children-s-publishing-in-china-highlights-from -the-first-gkc-china-deep-dive.html.

8. Peter Ford, "Sensing Subversion, China Throws the Book at Kids' Libraries," Christian Science Monitor, October 18, 2014, www.csmonitor.com/World/Asia-Pacific/2014 /1018/Sensing-subversion-China-throws-the-book-at -kids-libraries.

9. Kichiro Takahashi, “BUNKO: A Private Children's Library in Japan. A Short Introduction to Bunko” (World Library and Information Congress: 72nd IFLA General Conference and Council, Seoul, South Korea, 2006), http://ar chive.ifla.org/IV/ifla72/papers/081-Takahashi-en.pdf.

10. S. Takeuchi, "Bunko: Private Mini-Libraries for Children in Japan," Literacy: Traditional, Cultural, Technological: Selected Papers from the 23rd Annual Conference, International Association of School Librarianship, 1995, 1-4.

11. Aree Cheunwattana, "Bunko, the Home and Community Library in Japan: a Qualitative Study," Information Development 24, no. 1 (February 2008): 17-23, https://doi.org /10.1177/0266666907087693.

12. Junko Shiozaki, "Bunko in Japan: Studying the Trends of Bunko Operation and the Attitude of Bunko Operators," Library and Information Science, no. 70 (2013): 25-54. 